$\begin{array}{llllllllll}I & N & F & O & R & M & A & C & J & E\end{array}$

KS. HENRYK RYBUS

Archiwa, Biblioteki

i Muzea Kascielne

Tom 2, zeszyt 1-2.

\title{
KILKA UWAG O ZNISZCZONYCH AKTACH ARCYBISKUPÓW GNIEŹNIEŃSKICH 1 O NIEZNANYM ŻYCIORYSIE PIOTRA GAMRATA
}

W literaturze naszej poświęconej archiwoznawstwu i bibliotekarstwu znajduje się wiele niewystarczających a nawet błędnych informacji o zabytkach rękopiśmiennych przechowywanych w archiwach i bibliotekach kościelnych ${ }^{1}$. Podawanie należytych informacji uniemożliwiał często zły stan wspomnianych instytucyj, do tego stopnia, że w wielu miejscach nawet sami ich kierownicy czy opiekuni nie byli wystarczająco zorientowani co do zasobu i treści posiadanych zbiorów.

Edward Chwalewik i Karol Buczek, opracowując archiwa polskie?, najczęściej podawali informacje dotyczące archiwów kościelnych na podstawie ankiet wypełnionych przez kurie diecezjalne lub kierowników archiwów. Odpowiedzi te były pełne niezrozumiałej powściągliwości i najczęściej nie informowały należycie o zasobach archiwów. Nieraz też nie było żadnej odpowiedzi. W takim przypadku, gdy sprawa dotyczyła archiwum, którego zasób, dzięki pewnym wydawnictwom źródłowym, przynajmniej częściowo był znany, informacje autora były zbliżone do stanu rzeczywistego. Ale wśród polskich zbiorów kościelnych były również archiwa prawie zupełnie nieznane, których jednak zasoby zawierały źródła o wartości bardzo cennej dla historiografii zarówno kościelnej jak i politycznej. Takie znaczenie posiadały niektóre zespoły Archiwum Kurii Metropolitalnej w Warszawie, o którym K. Buczek podał za Chwalewikiem niezgodną ze stanem faktycznym wiadomość, że „Archiwum to ma charakter archiwum podręcznego dla celów kościelnych" " W wydanym później dodatku w stosunku do tegoż archiwum nie dokonano żadnego uzupełnienia ${ }^{4}$.

1 Por. J. Gryez: Przewodnik dla korzystajacych z bibliotek oraz spis dzieł pomocniczych. Kraków 1925 s. 136-144; St. K a tr z e ba: Historia źódeł dawnego prawa polskiego. Wyd. 2. T. 2. Lwów 1926 s. 437-445, 450-458; E. C h w a l ew i k: Zbiory polskie. Wyd. 2. T. 1-2. Warszawa 1926-1927; K. Bucze k: Archiwa polskie. "Nauka pol." T. 7: 1927 s. $1-97$; t. 12: 1930 s. $1-86$; S. D e m b y: Biblioteki, „Nauka pol." T. 7: 1927 s. $162-221$; t. 12 : 1930 s. $139-186$; J. Si emieński: Przewodnik po archiwach polskich. I. Archiwa dawnej Rzeczypospolitej. Warszawa 1933 s. $79-81$.

2 Prace cytowane w przyp. 1.

3 K. B u czek: Archiwa polskie. „Nauka pol.” T. 7: 1927 s. 85.

4 Jw. T. 12:1930 s. 1-86. 
Profesor historii Kościoła w Polsce na Uniwersytecie Warszawskim śp. ks. Henryk Likowski ( 1932 ) zwracał szczególną uwage swych uczniów na jeden wielki zespół wspomnianego archiwum, mianowicie na przedrozbiorowe akta arcybiskupów gnieźnieńskich, które za czasów arcybiskupa warszawskiego Zygmunta Szczęsnego Felińskiego wraz $z$ aktami konsystorza łowickiego zostały przewiezione z Łowicza do Warszawy ${ }^{5}$. Niestety całe Archiwum Kurii Metropolitalnej w Warszawie a z nim wszystkie tomy akt arcybiskupów gnieźnieńskich spłoneły podczas powstania warszawskiego w $1944 \mathrm{r}$.

Kierownikiem Archiwum Kurii Metropolitalnej i Archiwum Kapituły Katedralnej w Warszawie był w latach 1934 -1939 ks. mgr Władysław Kwiatkowski, jeden z uczniów ks. prof. Likowskiego. W czasie swojego urzędowania uporządkował on wspomniany zespół gnieźnieński, nadając mu może niezbyt właściwe miano Archiwum Prymasów Polskich ${ }^{6}$. Akta działalności arcybiskupów stanowiły przecież tylko główną część bogatego archiwum prymasów polskich. Na podstawie wspomnień i przechowywanych notatek ks. Kwiatkowski opisał spalone akta arcybiskupów gnieźnieńskich i opublikował w dwóch artylkułach w miesięczniku Ateneum Kapłańskie?.

W Archiwum Kurii Metropolitalnej Warszawskiej przeprowadzalem dwukrotnie kwerende w aktach arcybiskupów gnieźnieńskich: poraz pierwszy w r. 1933, poszukując materiałów do kościelnej działalności Fryderyka Jagiellończyka i ponownie w czasie ostatniej wojny w latach 1943-1944, zbierając materiały do zamierzonej monografii o kanonikach regularnych w Trzemesznie a jednocześnie do dziejów kolegiaty w Łasku. Ostatni raz wyszedłem $\mathrm{z}$ archiwum o godz. $13 \mathrm{w}$ dniu 1 sierpnia, w którym to o godz. 17 rozpoczęło się powstanie warszawskie.

Wszystkich akt arcybiskupich było około 160 voluminów; z nich przejrzałem i częściowo pofoliowałem 27, tj. od Jana Łaskiego do Wojciecha Baranowskiego. Owocem tej ostatniej niedokonczonej kwerendy były trzy teczki notatek (ok. 900 kartek) ułożonych tematycznie: 1) do dziejów opactwa w Trzemesznie, 2) do dziejów kolegiaty w Łasku oraz 3) odpisy i streszczenia zapisek o szczególnej wadze dotyczących różnych zagadnień i wzbudzających swą treścią szczególne zainteresowanie. Poza tym w osobnym zeszycie zaznaczałem miejsca w poszczególnych tomach zapisek, których treść mogłaby w przyszłości okazać się przydatną dla dziejów niektórych instytucyj kościelnych $z$ terenu dzisiejszej diecezji łódzkiej. Pierwsza i trzecia teczka zebranych materia-

5 Por. ks. Wł. K wiatkows ki: Prymasowska kapituła i kolegiata w Iowiczu (1433-1938). Warszawa 1938 s. 286.

6 Te $\mathrm{n} \dot{\mathrm{z}}$ e: Archiwum Archidiecezjalne Warszawskie. "Wiad. archidiec. warsz." R. 26: 1936 s. 283-295.

7 Ks. Wr. K wi a tk ow ski: Archiwum prymasów Polslí od XV wieku, „Ateneum kapl." T. 46: 1947 s. 297-301, 508-510; ten że: Zachowane odpisy dolkumentów i akt Archiwum Prymasów Polski. „Aten. kapł.” T. 48: 1948 s. $384-387$. 
łów zaginęły; częściowo zaś ocalała teczka druga - z materiałami do dziejów kolegiaty łaskiej, za wyjątkiem notatek z tomów od 5-8 akt arcybiskupów ${ }^{8}$.

Akta arcybiskupie należały do tego rodzaju archiwaliów, których przy opracowaniu pełnej działalności poszczególnych arcybiskupów gnieźnieńskich, jak i ogolnyci dziejów kościelnych w Polsce, pominąć nie było można. Do opracowań monografii historycznych poszczególnych biskupów niewątpliwie najwięcej materiału bezpośredniego zawierają same akta bıskupie, odzwierciedlają one bowiem niemal całkowitą ich działalność, przede wszystkim kościelną. Poza tym akta takie są zawsze bogatym źrodłem do dziejów wszystkich instytucyj kościelnych na terenie diecezji, zwłaszcza kościołów kolegiackich, parafialnych, klasztorów itp. ${ }^{9}$ Wszystko to $\mathrm{w}$ znacznie szerszym zakresie dotyczy akt arcybiskupich, gdyź były one jednocześnie aktami metropolity i prymasa. Dlatego też zniszczenie tych akt jeșt stratą ogromną i niepowetowaną dla historiografii kościelnej i świeckiej. Akta arcybiskupie nie były tylko protokółem czynności poszczególnych arcybiskupów. Poza materiałem nieraz b. cennym, bezpośrednio odnoszącym się do biografii (itinerarium, kalendarz czynności) arcybiskupów, akta te zawierały w sobie sprawozdania posiedzeń sądowych, odpisy nominacji na beneficja kościelne, wiadomości o synodach prowincjonalnych i archidiecezjalnych gnieźnieńskich, wiele materiałów dotyczących osób występujących $\mathrm{w}$ sporach sądowych czy w innych sprawach, wiele danych o stosunkach między instytucjami czy osobami, o ich stanie materialnym lub moralnym itd. Zapiski tych akt kryły nieraz ciekawy materiał; dotychczas nieznany, w relacji do osób czy zdarzeń, dający swą autentyczną rewelacyjnością zupełnie nowe i obiektywne naświetlenie, pozwalające na korekte dotychczasowych nieuzasadnionych poglądów i narosłych przez wieki uprzedzeń.

I tak np. o Wincentym de Sévé, bracie Sabiny żony Olbrachta Laskiego wojewody sieradzkiego, który w Polsce osiągnął zaszczytne stanowisko archidiakona gnieźnieńskiego oraz prepozyta łęczyckiego i łas-

8 „Habent sua fata libelli”. Owe trzy teczki notatek pozostawiłem w Warszawie przy ul. Tarczyńskiej 11, w mieszkaniu kolegi śp. d-ra Tadeusza Piotrowskiego, kustosza Bibl. Nar. i jego żony d-ra med. Heleny Piotrowslkiej-Kołodziejskiej. Dr Piotrowski zginą podezas powstania na Starówce. Wspomniane mieszkanie zostało splądrowane. Całe dwie teczlki notat przepadły. Trzecia teczke z wysypanymi kartkami pozostawiono, ale ok. 100 kartek i z niej zaginęlo. Zeszyt, o którym powyżej mowa, w czasie powstania został powierzony znajomej do przechowania. Nie wrócił jednak bezpośrednio po powstaniu do piszącego, ale przebył wędrówke poprzez obóz w Pruszkowie i obozy pracy w Niemczech, by wreszcie jesienia 1945 r. dotrzeé do rąk właściciela. Za ocalenie zawartych w nim resitek wiadomości dotyczacych akt arcybiskupów gnieźnieńskich należy się wdzięczność p. Janinie Przeradowskiej w Warszawie, która w pierwszy dzień powstania poniosła bolesna strate przez śmierć swego męża śp. Kazimierza Borkowskiego sędziego pokoju, zamordowanego w gmachu Gestapo przy al. Szucha.

9 Por. o. H. E. W y c z a ws ki: Wprowadzenie do studiów w arehiwach kościelnych. Warszawa $1956 \mathrm{~s} .72-74$. 
kiego, $\mathrm{z}$ akt arcybiskupa Stanisława Karnkowskiego można było dowiedzieć się nieznanego skądinąd szczegółu odnoszącego się do jego życia i kariery kościelnej. Prałat ten był w wielkim poważaniu u prymasa Karnkowskiego i jego dwóch bezpośrednich następców - arcybiskupa Tarnowskiego i kardynała Bernarda Maciejowskiego. Jego dzialalność, jako nieprzeciętnego znawcy prawa kościelnego i państwowego, na stanowisku archidiakona gnieźnieńskiego była wyjątkowo pozytywna i ruchliwa. Oprócz tego oddał on niemałe usługi swym protektorom gnieźnieńskim jako kilkakrotny poseł do kurii rzymskiej ${ }^{10}$.

Ks. Korytkowski wymienia cztery jego podróże do Rzymu, z których pierwsza w sprawie zatwierdzeń królewskich i arcybiskupich nadań na korzyść Zakonu Jezuitów miała mieć miejsce w roku 1600. Otóż w aktach arcybiskupa Karnkowskiego pod rokiem 1594, w związku z wyniesieniem Wincentego de Sévé (po śmierci Erazma Kretkowskiego) do godności archidiakona, była wzmianka o jego dotychczasowych zasługach względem arcybiskupa i kapituły, a szczególnie z powodu jego, do tej pory dwukrotnego, posłowania do Stolicy Apostolskiej. Podczas drugiej podróży, w drodze powrotnej przez Alpy, poseł kapituły gnieźnieńskiej został napadnięty przez bandytów i w utarczce z nimi, w obronie życia swojego i towarzyszy zabił jednego $z$ opryszków, przez co jako duchowny popadł $\mathrm{w}$ nieregularność kanoniczną (propter homicidium). Dlatego musiał postarać się o dyspensę papieską ab irregularitate. Odpis dyspensy znajdował się w aktach prymasa Karnkowskiego pod rokiem 1594.

Z aktami arcybiskupów zaginęły bezpowrotnie dość liczne wzmianki dotyczące synodów archidiecezjalnych i prowincjonalnych gnieźnieńskich. Zawierały one często bardzo wiele materiału, skądinąd nieznanego lub uzupełniającego źródła wykorzystane dotychczas w opracowaniach synodów. Na podstawie posiadanych na ten temat uwag z przejrzanych 27 tomów akt arcybiskupich można stwierdzić istnienie w nich wzmianek o synodach Jana Łaskiego, Macieja Dziewickiego, Jana Latalskiego, Piotra Gamrata, Jakuba Uchańskiego i i. Z czasów prymasa Karnkowskiego (1581-1603) było pięć tomów akt arcybiskupich, każdy liczący ok. 500 kart, zawierających ogrom niewylsorzystanego materiału do szczególnie ruchliwej i dla Kościoła w Polsce niezmiernie ważnej działalności tego hierarchy $\mathrm{z}$ okresu reformy trydenckiej. $W$ aktach Karnkowskiego $m$. in. były wpisane in extenso mowy tegoż prymasa wygłoszone w języku łacińskim podczas uroczystości poświęcenia kolegium jezuitów w Kaliszu w 1596 r. ${ }^{11}$ Synody archidiecezjalne i prowincjalne tegoż prymasa znalazły tutaj nieraz pełne odzwiercedlenie, jak np. cały przebieg synodu prowincjonalnego odbytego $\mathrm{w}$ Piotr-

10 Por. ks. J. Korytkowski: Prałaci i kanonicy katedry metropolitalnej gnieźnieńskiej T. 3. Gniezno $1883 \mathrm{~s} .463-474,593$; Ks. H. R y b u s: Biblioteka kolegiaty łaskiej. Łódź 1939 s. 8 n.

11 Por. K. Estreicher: Bibliografia polska XIX 120. 
kowie w 1589 r. z dwiema mowami Karnkowskiego na rozpoczęcie i zakończenie, czy archidiecezjalnego w Łowiczu w 1593 r., również z pełnym tekstem arcybiskupiej ekshortacji wygłoszonej do kleru w języku łacinskim ${ }^{12}$. W aktach arcybiskupa Wojciecha Baranowskiego (vol, 27 k. $485 \mathrm{nn}$.) znajdował się pełny tekst ustaw synodu archidiecezjalnego odbytego w Gnieźnie 9 maja 1612 r. ${ }^{13}$

$\mathrm{Na}$ podstawie akt arcybiskupich można było odtworzyć itineraria poszczególnych prymasów. Marginesowe lub międzytekstowe luźne zapiski zawierały wiadomości o stanie zdrowia, chorobie arcybiskupów; nieraz śmierć arcybiskupa podawana była przez notariusza w szczegółowym nekrologu. Wszystko to mogło przysporzyć wiele cennego materiału źródłowego do życiorysów i charakterystyki arcybiskupów gnieźnieńskich. Zaczerpnięty stamtąd materiał biograficzny mógł w niejednym wypadku, w zestawieniu $\mathrm{z}$ innymi bardziej subiektywnymi przekazami, przyczynić się do bliższego historycznej prawdzie osądzenia działalności i moralnej wartości niektórych prymasów, zwłaszcza gdy bez współczesnej solidnej podstawy źródłowej opierano ocenę na opinii tendencyjnie fałszywej, wypowiadanej przez ludzi niechętnie lub nawet wrogo do nich usposobionych.

Spośród episkopatu polskiego w okresie pełnego rozkwitu renesansu za panowania Zygmunta Starego wielkie zaciekawienie wzbudza osoba Piotra Gamrata biskupa krakowskiego i arcybiskupa gnieźnieńskiego, postać będąca jakby uosobieniem i ześrodkowaniem najbardziej przeciwstawnych cech tej epoki. Zdaje się jednak, że o Gamracie dotychczasowa historiografia, nieuwzględniająca należycie jego nader pozytywnej i jednocześnie łatwo sprawdzalnej działalności kościelnej, wypowiedziała chyba najwięcej niesprawiedliwych sądów i krzywdzących opinii, jakoby zniewolona rzekomo autentyczną i obiektywną oceną ludzi mu współczesnych.

Prof. Kazimierz Hartleb, zajmujący się już od wielu lat badaniami nad kulturalnym mecenatem ludzi Odrodzenia, na krótko przed wojną skierował swe zainteresowania na osobę Gamrata, któremu nawet zamyślał poświęcić obszerną monografię. Zamiary te przerwała jednak przedwczesna śmierć wybitnego historyka. W wydanej na rok przed wojną pracy o arcybiskupie Gamracie ${ }^{14}$ przeprowadza on w szerokim wywodzie analizę jego życiorysu zaczerpniętego z kopii sporządzonej przez Wojciecha Kętrzyńskiego z rękopisu pochodzącego z ok. 1620 r.

12 Tamże XIX 122, XXX 140; por. J. S a w i ck i: Synody archidiecezji gnieźnień:kiej i ich statuty. W: „Concilia Poloniae”. T. 5. Warszawa 1950 s. 177-182.

13 Por. J. S a w i ck i, jw. S. 203-206.

$14 \mathrm{~K}, \mathrm{H}$ a r t le b: Piotr Gamrat w świetle nieznanego życiorysu. „Archiwum TN we Lwowie". Dział 2. T. 21 z. 2. Lwów 1938. Pelny życiorys Gamrata pióra tegoż autora znajduje siẹ w ,Pol. Słown. biogr.” VII 264-266. Zarówno w jednej jak i drugiej pracy pominięte zostały archiwa kościelne. 
a znajdującego się w bibliotece Michała Szczanieckiego w Nawrze koło Chełmży. Rękopis ten zawierał życiorysy Piotra Tomickiego i Piotra Gamrata z. wyraźnym wskazaniem autora, a mianowicie Filipa Padniewskiego. Rękopis ów, niezawodnie kopia innego znacznie starszego rękoipisu, pochodzącego może z drugiej połowy XVI wieku, był w posiadaniu Tomickich, rodziny biskupa i podkanclerzego Piotra. Hartlebowi nie udało się dotrzeć do oryginału. We wnikliwych dociekaniach zmierza-jących do ustalenia autorstwa życiorysu Gamrata wziął on pod uwage trzech współcześnie żyjących ludzi: Stanisława Górskiego kanonika krakowskiego i sekretarza królewskiego, Stanisława Hozjusza póżniejszego biskupa warmińskiego i kardynała oraz Filipa Padniewskiego, wówczas również sekretarza królewskiego, późniejszego podkanclerzego i biskupa krakowskiego.

$\mathrm{Na}$ podstawie porównania tekstu życiorysu z całym szeregiem pozbieranycn z roznycn pism Gorskiego wypowiedzi w Iormie dosadnych, lapıaaniych i w trescı b. ujemnycn okresleń Gamrata odrzuca Hartleb nıpotezę jego autorstwa. Argumentem dla takiej decyzji - to oczywiste roznice styustyczne zachoazące pomięazy zebranymi inwektywami a tekstem życiorysu. Hipotezę zaś dutorstwa Stanisława Hozjusza, jaką nasunęłaby okolicznośc złączenia w jednym rękopisie życiorysu Tomickiego z życiorysem Gamrata, uważa Harıleb również za niemożliwą cio przyjęcia a to ze względu na wielkie różnice jego metody pisarskiej, polegającej na hołdowaniu ścisłemu porządkowi cnronologicznemu, oraz na swoisty i charakterystyczny styl Hozjusza, o dużym zacięciu literackim i walorach klasycznych, których to cech brakuje w omawianym żywocie. Przychyla się zatem za przyjęciem autorstwa Filipa Padniewskiego, przynajmniej uważa je za barazo prawdopodobne. Stara się też przyloczyć jak najwięcej dowodów przemawiających za tym autorstwem. Przede wszystkim nie można jego zdaniem zlekceważyć wyraźnej wskazówki samego rękopisu. Właśnie ta okoliczność wpłynęła dość sugestywnie na dobór argumentów. Szeroko rozpisuje się autor o zdolnościach pisarskich Padniewskiego, jego wyksatałceniu, obcych wpływach, a zwłaszcza metody pisarskiej krótkich biografii Pawła Joviusa, z którym Padniewski zetknął się nawet osobiście podczas swych pobytów we Włoszech. Podwójny niejako charakter życiorysu - podkreślenie pozytywnych stron działalności Gamrata i dodatnich cech jego charakteru z jednoczesnym zgrupowaniem faktów niezgodnych $z$ prawdą i ostatecznie ujemnym scharakteryzowaniem całej postaci stara sie autor wytłumaczyć rzekomą zmianą poglądów Padniewskiego, zaszłych pod wpływem Stanisława Górskiego, z którym tenże pozostawał w bliskich stosunkach i który, zarówno na zmarłych jak i żyjących, miał zwyczaj w sposób niepohamowany rzucać oszczercze inwektywy i pomniejszać ich znaczenie u współczesnych i potomnych ${ }^{15}$.

15 K. H a rtle b: Piotr Gamrat w iświetle nieznanego życiorysu s. 66-99. 
Atoli autorstwo Padniewskiego jest nie do przyjęcia z kilku względów. W stosunku do życiorysu Tomickiego, będącego przeróbką pracy Hozjusza, trudno zgodzić się z tezą o autorstwie Padniewskiego, który Tomickiego znał osobiście i na tyle cenił swe zdolności pisarsłkie, że życiorys swego protektora mógł opracować samodzielnie. W relacji do drugiego życiorysu zupełnie dowolnym jest przypuszczenie nie stwierdzonej żadnymi:innymi przekazami źródłowymi krańcowej ewolucji poglądów Padniewskiego na osobe Gamrata i to pod wpływem zapatrywań Górskiego, którego rzekomą obiektywnóść oceny ludzi miał on okazję poznać już o wiele wcześniej za życia Gamrata, gdy ten piął się dopiero po szczeblach kariery duchownej. Pomimo pewnej niechęci samego Tomickiego w stosunku do Gamrata nie uległ wówczas. Padniewski opini swego poważnego protektora i przełożonego w kancelarii królewskiej, ale wspomnianego podziwiał i z sympatią patrzył na jego sukcesy. Zresztą po osiągnięciu przez Gamrata krakowskiej stolicy biskupiej: Padniewski, będący kanonikiem krakowskim, częściej zaczął się, z nim. stykać, a później, darzony przez swego biskupa à następnie i prymasa szczególnym zaufaniem, w jego sprawach jeździł do Rzymu. Co więcej - jako prawnik asystował arcybiskupowi na rozprawach sądowych. Są też wyraźne ślady sprawowania przez Padniewskiego urzędu notariusza w arcybiskupiej kurii Gamrata. Rozpatrywany przez Hartleba życiorys, którego teksl jakby złożony z dwóch przeciwstawnych opracowań pełen jest sprzeczności, trudno przyjąć za produkt pisarski Padniewskiego. Byłoby to jenocześnie zaprzeczeniem wysokiej oceny pisarskiej. indywidualności Padniewskiego wypowiedzianej na innym miejscu. Wreszcie nasycenie życiorysu gwałtowną niechęcią w stosunku do królowaj Bony, której łaskawości doznał w swym życiu także i Pàdniewski, musi stanowczo przekreślić hipoteze o jego autorstwie.

Omawiany życiorys wydaje się świadomia tendencyjny. Właściwemu autorowi a raczej kompilatorowi obu źyciorysów (tj. Tomickiego i Gamrata) przyświecała myśl, aby w sposób najbardziej plastyczny. uwydatnić bezkrytycznie uwielbianą i idealizowaną postać Tomickiego. Dlatego posłużył. się umyślnie spreparowanym rzekomym niemal pod każdym względem kontrastem, przeciwstawiając Tomickiemu Gamratá. Ale przecież zupełnie na czarno nie można było malować tego ostatniego; dla sfingowania obiektywizmu trzeba było użyć nieco także i.jaśniejszych tonów.

Obydwa życiorysy były najprawdopodobniej napisane specjalnie na użytek rodziny zmarłego podkanclerzego Tomickiego. I tylko Stanisław Górski mógł wpaść na taki pomysł; aby. uwielbianego protektora swego, jaśniejącego cnotami.i zasługami; przedstawić w zestawieniu z ciemną sylwetką Gamrata ${ }^{16}$. Różnicy stylowej zachodzącej pomiędzy Juźnymi wypowiedżiami Górskiego o Gamracie a tekstem życiorysu nie 1909.

1.6. W. Z akrzew ski: Stanisław Górski. i jego prace historyezne. Kraków 
można uważać za dostateczny argument wykluczający autorstwo Górskiego. Różnice te wynikają z samej odmienności formy utworów. I Górskiego pióro mogło sobie poradzić w napisaniu biografii odznaczającej się pewnymi pozorami jedności stylowej przez złagodzenie swych zwykle trywialnych określeń, rzucanych przygodnie o Gamracie, nadając im bardziej literacką formę. Dla zyskania pozorów autentyczności całej treści życiorysu posłużył się Górski nazwiskiem Padniessskiego, o którym powszechnie wiedziano, iż patrzył z bliska na działalność i życie Gamrata i, że w ostatnich latach był nawet na jego usługach. Zasugerował więc Górski innym autorstwo Padniewskiego.

Taka sugestia Górskiego nie mogła jednak wyrosnąć jedynie $z$ jego fantazji. W kołach kancelarii królewskiej i kapituły krakowskiej Padniewski musiał uchodzić za autora jakiejś biografii Gamrata. Samo użycie formy określającej to autorstwo w sposób "auctore Philippo Padniewio" było, jak się przekonamy, autentyczne; Padniewski właśnie jakby firmował autentyczność napisanego przez siebie żywotu. Gamrata.

Przejdźmy znów do zaginionych akt arcybiskupich. Z czasu prymasowskich rządów Gamrata (1540-1545) pozostały trzy tomy akt. Pierwszy tom rozpoczął Gamrat w księdze akt arcybiskupich swego poprzednika, Jana Latalskiego. Księga ta jako 6 tom ogólnego zbioru zawierała akta za okres od 1539 do 1540 r. Latalski umarł 29 VIII 1540. Potem szły akta administratora archidiecezji Szymona Chabielskiego do 6 III 1542, a więc już po wyniesieniu Gamrata na stolice arcybiskupią. Gamrat, chociaż już uzyskał 25 III 1541 zatwierdzenie Stolicy Apostolskiej na arcybiskupstwo i pozwolenie jednoczesnego zatrzymania biskupstwa krakowskiego, swoje akta arcybiskupie rozpoczął dopiero w marcu następnego roku. Zapiski te obejmowały czas od 6 III 1542 do 23 X 1543 i stanowiły pierwszy tom jego akt arcybiskupich. Drugi tom akt działalności Gamrata jest 7 księga zbioru ogólnego. Zamykała ona okres od końca pażdziernika $1543 \mathrm{r}$. do końca maja $1545 \mathrm{r}$. Tom 8 akt stanowił w swej początkowej części trzeci tom akt Gamrata i zawierał zapiski za okres od kwietnia 1545 r. do 27 VIII 1545 r. tj. do dnia śmierci tego arcybiskupa. Od karty 84 tego tomu rozpoczynały się akta administratora sede vacante Jana Kokalewskiego, zawierające zapiski za czas od grudnia 1545 r. do listopada 1546, kończąc się na karcie 235, na odwrociu której rozpoczynały się już akta nowego arcybiskupa Mikołaja Dzierzgowskiego zapiskami ze stycznia $1547 \mathrm{r}$. Ostatnie zapiski tego tomu, ze stycznia 1548 r., zajmowały drugą stronę karty 494; końcowa część tego tomu tj. do karty 597 była niezapisana.

Rozmyślnie ósmemu tomowi akt arcybiskupich a trzeciemu prymasa Gamrata poświęciliśmy więcej uwagi, albowiem na jego kartach był oryginalny, własną ręką Padniewskiego pisany życiorys świeżo zmarłego naszego arcybiskupa. Przy końcu karty 82 wypisany był szczegółowy nekrolog na cześć zmarłego $\mathrm{z}$ dokładnym podaniem czasu, miejsca i przyczyny zgonu. Na odwrociu tejźe karty, od samej góry biegł tekst życiorysu z tytułem zupełnie prostym, bez żadnych uwzględnien urzę- 
dowej tytulatury arcybiskupa, a mianowicie "Vita Petri Gamrath". Żywot ten kończył się nisko na odwrociu karty 83 w sposób następujący: "auctore Philippo Padnievio notario, qui manu propria scripsit". Niestety tekst odpisanego nekrologu i życiorysu zaginął. Jego brak uniemożliwia konfrontację z życiorysem rozpatrywanym przez Hartleba. Jednakże takie porównanie było dokonane przed zaginięciem tekstu. Życiorys gnieźnieński nie był panegirykiem napisanym ku chwale zmarłego arcybiskupa, chociaż zawierał wiele szczegółów naświetlających w sposób pozytywny kościelną a zwłaszcza polityczną działalność Gamrata. Autor przedstawił w kolejności chronologicznej bieg życia swego bohatera, osiąganie coraz wyższych godności kościelnych dzięki szczególnej łaskawości władców (principum), bez wyraźnego podkreślenia imienia królowej Bony, jako głównej sprawczyni wywyższenia Gamrata. Nie brak też było akcentów podkreślających zasługi dla diecezji krakowskiej i gnieźnieńskiej zwłaszcza przez wspomnienie działalności synodalnej. W charakterystyce osobowości Gamrata zwrócił autor uwage na wybitne zdolności umysłowe, jego niezwykłą pamięć, chłonność umysłu, łatwość publicznego przemawiania. Z cech jego charakteru podkreślone zostały gościnność, umiejętność jednania sobie ludzi i przyjaciół wśród wszystkich sfer (nie jakaś specyficzna propensja do ludzi niskiego pochodzenia), owa liberalitas i humanitas, tak cenione przez ludzi tej epoki a należące w wysokim stopniu do zasadniczych przymiotów Gamrata. Opis fizycznej postaci arcybiskupa jest tu identyczny $z$ opisem życiarysu Hartleba za wyjątkiem złośliwego dodatku o braku należytej powagi. Padniewski kończy życiorys wspomnieniem, że Gamrat nie dbał o swoje zdrowie, które nawet nadwyrężył wystawnymi ucztami (gdyż liważał je za konieczne dla wytworzenia odpowiedniej atmosfery, sprzyjającej·owocnym rozınowom i naradom w sprawach publicznych) oraz stwierdzeniem ostatecznej przyczyny śmierci, jaka do posiadanych już chorób żołądka i podagry doszła jeszcze w formie wyrosłego między łopatkami karbunkułu. Pochodzenie Gamrata przedstawione było w życiorysie gnieźnieńskim jako bez żadnej wątpliwości szlacheckie z obojga rodziców. Ojciec jego Stanisław pieczętował się herbem Sulima „nobili genere natus ex utroque parente, patre Stanislao ex stemmate Sulimeorum".

Opisany żywot Gamrata niewątpliwie wyszedł spod pióra Padniewskiego, który, jako notariusz kurii arcybiskupiej, miał dostęp do akt prymasa. Akta te znajdowały się przed samą śmiercią przy arcybiskupie, a więc w Krakowie $i$ do nich też niemal zaraz po śmierci Gamrata ów życiorys został wpisany. Padniewski równo na rok przed śmiercią Gamrata (27 sierpnia 1545 r.) przygotowywał się do wyjazdu za granicę, jako poseł jego do Rzymu. W dniu tym bowiem, przewidując długotrwałą nieobecność w kraju, ustanowił aż czterech swoich prokuratorów w osobach współtowarzyszy z kapituły krakowskiej, a mianowicie: Stanisława Borka, Benedykta Izdbieńskiego, Jakuba z Kleparza i Zygmunta ze Stężycy, aby mogli w jego imieniu załatwiać sprawy związane 
$\mathrm{z}$ beneficjami kościelnymi. i występować w sądach ${ }^{17}$. Ten ostatni przed śmiercią Gamrata pobyt Padniewskiego we Włoszech trwał prawie rok. Wrócił do Krakowa zaledwie na kilka dni przed zgonem arcybiskupa, lecz za jego życia nie zdążył już złożyć relacji ze swej podróży ${ }^{18}$. Widzimy go po raz pierwszy po przyjeździe na sesji nadżwyczajnej kapituły krakowskiej 27 sierpnia 1545 r., zwołanej natychmiast po stwierdzeniu zgonu Gamrata. Ponieważ arcybiskup zmarł nie sporządziwszy uprzednio testamentu, kapituła na sesji tej z grona swego wydelegowała sufragana Erazma opata mogilskiego, archidiakona Bartłomieja Gantkowskiego, kantora Benedykta Izdbieńskiego i naszego kanonika Padniewskiego 2 poleceniem, aby zaraz udali się do domu zmarłego i sporządzili spis pozostałych po nim rzeczy ${ }^{19}$. Do delegacji kapituły przyłączył się wysłany przez króla kanclerz koronny Tomasz Sobocki. Wobec takiej komisji skarbnik arcybiskupa Tomasz Swieborowski spisał w oddzielnej księdze pozostałe po Gamracie pieniądze, kosztowności i wszystkie rzeczy znajdujące się wówczas w kurii zmarłego ${ }^{20}$. Z tytułu inwentarza dowiadujemy się godziny, w której nastąpiła śmierć; była to według ówczesnego sposobu obliczania czasu godzina 16-ta.

Był zatem Padniewski w Krakowie, kiedy Gamrat żegnał się ze światem. Najprawdopodobniej był przy łożu umierającego. W udziale też przypadło i jemu szacowanie pozostałego po zmarłym majątku. W ciągu kilku dni po śmierci, jeszcze przed pogrzebem, musiał napisać biografię Gamrata, by ją przed zabraniem ksiąg arcybiskupich do Gniezna czy Łowicza, zdążyć wpisać do tomu ósmego akt. Tom ten, jak wyżej widzieliśmy, służył w dalszym ciągu administratorowi archidiecezji Janowi Kokalewskiemu i następcy zmarłego - Mikołajowi Dzierzgowskiemu. Prawdopodobnie delegacja kapituły gnieźnieńskiej, obecna 15 września ra pogrzebie prymasa, opuszczając Kraków zabrała ze sobą księgi arcybiskupie. Przed tym też terminem wspomniany życiorys musiał już znajdować się w trzecim tomie akt arcybiskupich Gamrata. Wszystkie okoliczności przemawiają za tym, że pierwsza biografia Gamrata napisana przez Filipa Padniewskiego była gotowa jeszcze przed złożeniem jego zwłok w katedrze na Wawelu.

Ze zniszczeniem akt arcybiskupich zaginął również tekst życiorysu pióra Padniewskiego. Innego rękopisu z tym tekstem nie znamy. Jednak, jak sie zaraz przekonamy, nie zupełnie przepadła treść pierwszej biografii Gamrata.

17 Archiwum Kapituły Krakowskiej. Acta actorum. Vol. 4 k. 28 v.

18 Relacje taka złożył kapitule w dniu 31 sierpnia, jeszcze przed pogrzebem Gamrata. Tamże k. 91.

19 Tamże k. 89.

20 Arch. Kapit. Krak. Inventarium omnium et singulorum rerum morte acerbissima $\mathrm{r}-\mathrm{mi}$ in Chrto patris et d. d. Petri a Gamrathis D. g. archiepi Gnesn. etc. derelictarum. (Bez sygn.). Por. ks. I. P olk owski: Spadek po prymasie, areybiskupie gnieźnieńskim i biskupie krakowskim, Piotrze Gamracie. „Rozpr. i sprawozd. z posiedz. Wydz: Hist.-Filoz, AU', T, 21: 1888 s. XXX-LII. 
Piotr Gamrat okazał się niezmiernie systematyczny i prawie pedantyczny w nieprzerwanym prowadzeniu dwóch równoległych kancelarii: krakowskiej i gnieźnieńskiej. Rekompensatę więc w pewnym stopniu za przepadłe akta arcybiskupie $\mathrm{z}$ jego czasów stanowią biskupie akta krakowskie. Poza Archiwum Kapitulnym Krakowskim, częściowo wYkorzystanym już przez biografów Gamrata, do dziejów jego działalności kościelnej stoją przed historykiem do dyspozycji nietknięte jeszcze akta konsystorza gen. krakowskiego. Z czasów nas interesujących mamy tutaj cztery tomy akt biskupich prowadzonych chronologicznie od 1538 do $1545 \mathrm{r}$. Oprócz nich - dwa dalsze tomy takichże akt, ale osobno prowadzonych $\mathrm{z}$ wyodrębnioną specyfikacją spraw, a więc: jeden tom stanowiący kopiarz dokumentów za rok 1545 (poprzednie pewno zaginęły) i drugi zawierający nominacje i instytucje duchowieństwa na beneficja kościelne za okres od 1538 do 1545.

Trzeba zaznaczyć, że Gamrat należał do tych nielicznych biskupów krakowskich, którzy prowadzili oddzielnie "Institutiones". Przed nim prowadzili te księgi: Jan Konarski - 2 tomy i Piotr Tomicki - 1 tom. Po Gamracie czynił to tylko Samuel Maciejowski. Zatem w Krakowie z czasów Gamrata pozostało sześć tomów akt biskupich ${ }^{21}$. Nawiasem zaz.naczyć wypada, że za cały okres biskupich rządów Filipa Padniewskiego (1560-1572) pozostał tylko jeden tom akt biskupich, zawierający 483 karty ${ }^{22}$.

Na ostatnich kartach 4-go tomu akt biskupich Gamrata (k. $465 \mathrm{v}-$ 467) wpisany został niezawodnie wkrótce po śmierci życiorys zmarlego arcybiskupa. Życiorys ten zatytułowany „Vita et dies mortis“" podpisał własnoręcznie notariusz zmarłego arcybiskupa Bartłomiej Siekierzecki. Nie wiemy o tym notariuszu żadnych szczegółów poza tym, że był on jednocześnie proboszczem w Ślesinie, a więc należał do kleru archidiecezji gnieźnieńskiej ${ }^{23}$. Trudno uważać go za oryginalnego autora wpisanego życiorysu. Właściwie on poświadcza wiarogodność odpisu dokonanego przez innego pisarza, gdyż cały tekst życiorysu napisany został inną ręką. Notariusz Siekierzecki prawdopodobnie przygotował do

21 Oprócz sześciu tomów „episcopalisów” w Archiwum Konsystorskim w Krakowie z czasów Gamrata pozostaja jeszcze następujące ksiegi: 1) Acta officialia nr $5(1533-1539), 6(1540-1547), 52(1534-1538), 71(1540-1541), 72$ (15411542), 73 (1542-1544), 74 (1544-1545), 75 (1545); 2) Acta actorum vicarialia $\mathrm{nr} 62$ $(1537-1540), 76(1541-1542), 77(1542-1544), 78$ (1544-1545); 3) Pronuntiationes (nazwiska stron i terminy ich spraw) nr 66 (1541-1543), 67 (1543-1544); 4) Constitutiones procuratorum $\mathrm{nr} 56$ (1528-1538), 64 (1540-1542), 68 (1542-1545); 5) Obligationes nr $53(1538-1540)$; 6 Sententiae nr 54 (1538-1540).

22 Archiwum Kons. w Krakowie. Acta episcopalia. Vol. 29. Ostatnią zapiska jest tu pod r. 1572 wy.szły spod pióra notariusza Wojciecha Pruszkowskiego następujący krótki nekrolog Padniewskiego: „Anno eodem die 17 aprilis in commiciis generalibus Warschaviensibus r-mus in Chr-o p-r d. d. Philippus Padniewski D. g. epus Cracovvitam cum morte commutavit, cuius mortem rex et senatus totus moestus deplora. bat". Jego biografii w aktach biskupich nikt nie zamieścil.

- 23 Ks. I. Kor y kow s. i: Arcybiskupi gnieźnieńscy. T. 3. Poznań 1889 S. 123 , 
wpisania w aktach krakowskich jakiś życiorys Gamrata ale nie zredagował go samodzielnie. Otóż niezawodnie obecność żywotu Gamrata w aktach arcybiskupich gnieźnieńskich spostrzeżona przez notariusza stała się bezpośrednim bodźcem do napisania podobnego życiorysu i $\mathrm{w}$ aktach biskupich krakowskich. Najłatwiej byłoby przepisać. Ale wówczas trzeba by zaznaczyć autorstwo Padniewskiego. Powstał zatem nowy życiorys ale właściwie niemal $w$ całej treści zależny od pierwszego. Jest to niezupełnie dosłowne powtórzenie życiorysu Padniewskiego z akt gnieżnieńskich. Sa tu w porównaniu z tamtym pewne nieznaczne opuszczenia, takie jak: imię ojca Gamrata, wzmianka o jego działalności kościelnej, zwłaszcza synodalnej, opis fizycznej postaci arcybiskupa. Reszta nie różni się wcale. Pod życiorysem krakowskim dodano wiersz łaciński, jako nagrobek dla zmarłego arcybiskupa - aepitaphium eiusdem. Wspomniany dopiero co wiersz łaciński przeciwstawia Rzym Krakowowi oraz św. Piotra Piotrowi Gamratowi. Wiersz ten nie stanowi tekstu późniejszego nagrobka wystawionego Gamratowi przez królowę Bonę. Nie jest on też płodem notariusza Siekierzeckiego ale dosłownie został odpisany $\mathrm{z}$ akt gnieźnieńskich, gdzie znajdował się jako dalszy ciąg nekrologu Gamrata, napisanego bezpośrednio przed życiorysem. Prawdopodobnie autorem i tego napisu był Padniewski. On to, mający świeżo w wyobraźni obraz Wiecznego Miasta po niedawnym powrocie do kraju, mógł użyć tak parabolicznego porównania Gamrata z Księciem Apostołów i stolicy Polski ze stolicą Chrześcijaństwa.

Poza omówionym powyżej życiorysem z akt biskupich Archiwum Konsystorskiego $\mathrm{w}$ Krakowie, który na tym miejscu publikujemy, istniał jeszcze jeden niewydany dotychczas życiorys w rękopisie Archiwum Kapitulnego Katedry Krakowskiej, zawierający kontynuację Długoszowego katalogu biskupów krakowskich ${ }^{24}$. Rękopis ten niestety, jak informuje dyrekcja wspomnianego archiwum, zaginął $w$ ostatnim dwudziestoleciu. Znajdujący się w nim krótki życiorys Gamrata pochodził prawdopodobnie $\mathrm{z}$ XVII wieku.

\section{ŻYCIORYS PIOTRA GAMRATA}

Archiwum Konsystorskie w Krakowie.
Acta episcopalia. Vol, 21 k. $465 \mathrm{v}-467$.

Vita et dies mortis

Petrus Gamratus aequestri ordine, gente Sulimeus, parentibus non perinde claris ortus. Adolescens admodum relictis litterarum studiis aulico Erasmi Vitellii ${ }^{1}$ episcopi Plocensis, gravissimi et splendidissimi

24 Ks. I, Pokow s ki: Katalog rękopisów katedry krakowskiej. „Arch. do dziejów liter. i oświaty w Polsce”. T. 3. Kraków 1884 s. 135.

1 Erazm Ciołek biskup płocki (1503-1522). 
viri, ministerio sese addixit. Cumque eo legato ad cesarem ${ }^{2}$ et summum pontificem ${ }^{3}$ profectus domum et familiam eius omnem gubernavit. Eo defuncto reversus, in Mazovia, prepositus Poltoviensis et primum scholasticus deinde decanus Plocensis, privatam duxit vitam, Nicolai Hussovii ${ }^{4}$, boni et litterati viri, consuetudine utens. Unde ad Camenecensem episcopatum ultro oblatum evocatus, cum vix amicis suadentibus et impellentibus acquievisset, et paulo post a rege ${ }^{5}$ gubernator in Mazoviam remissus est. Quam provinciam cum dextere et magno fisci regii compendio sine querimoniis hominum administrasset. Ad Premisliensem, inde intra biennium ad Plocensem episcopatum lubens, paulo post ad Cracoviensem, non item lubens, principum ${ }^{6}$ non obscuro favore et autoritate translatus est. Biennio denique post archiepiscopatum ${ }^{7}$ oblatum ea lege, ut Cracoviam simul retineret, accepit. Non facile Cracovia discedere permissus, absentibus iuxta ac presentibus principibus, qui in eius consiliis, sive quid constituendum esset de republica, sive honores et magistratus mandandos, seu quid denique privati negocii intervenisset, libenter acquiescebant, ita ut ab eis, nisi quod nollet impetrare non posset, cum fidem et obsequium suum ipsis spectaculum reddidisset. Quamobrem emulorum quorundam opera et obtrectationibus versa in invidiam gratia populari, qua multum valuerat, non satis potuit ea, que de republica bene et utiliter, ut sibi videatur, vere quidem certe et ex animo in medium consulebat perficere, principum visus studiosior, quam placere aut axpedire videretur. Fuit autem ingenio prompto, memoria singulari, prudentia et iudicio supra hominum opinionem. Cum litteris Rome apud Vitellium (cuius domus ac mensa perinde atque academia quedam doctoribus omnis generis referta erat) et in Mazovia ex contubernio Hussovii mediocriter tinctus est ad doctos et virtute aliqua preditos homines sine ullo fere discrimine augendos et ornandos propensus. In componendis litibus et sedandis summorum pariter atque inferiorum hominum discordiis et inimiciciis ectiam cum detrimento rei sue familiaris sedulus atque dexter. In dicenda in senatu sententia liber, in sermone candidus et non operosus. In familiari vite consuetudine comis, nisi quod facile excandescebat, sed mox ad se redibat. Credulus quippe, qui alios de suo ingenio metiretur. Amicicias alieno fere magis quam suo arbitratu coluit, in deponendis vel dissimulandis inimiciciis et condonandis offensis perfacilis. Noxius nemini sua quidem sponte vel data opera, totus denique ad liberalitatem et beneficienciam factus, quam ad prodigilitatem usque exercuit. Valetudine corporis varia quippe, quam liberiore anteacte aetatis vita et crebris prolixisque conviviis afflixisset. Dum partim externis hominibus hospitalitatem cum magnificencia coniunctam ostendat, partim graciam atque be-

2 Cesarz Maksymilian (1493-1519).

3 Papiez Leon $X$ (1513-1521).

4 Mikołaj Hussowezyk poeta i humanista, dworzanin Erazma Ciołka.

5 Król Zygmunt I (1506-1548).

6 Król Zygmunt I i królowa Biona (1518-1557).

7 Arcybiskupstwo gnieźnieńskie. 
nivolenciam multorum ad res gerendas in republica hoc tempore ferme mecessariam sibi.consiliat. Calculum, podagram et ultimis aliquot annis stomachi imbecillitatem familiares morbos habuit. Ad extremum carbunculo inter scapulos enato extinctus est, annum agens quinquagesimum octavum, anno Domini millesimo quingentesimo quadragesimo quinto, V.I Cal. septembris.

\section{Aepitaphium eiusdem}

Petro Roma suo gaudet, Cracovia Petro

Non minus exultat. Nomine namque parens.

Una nocte suum ter prodidit ille Magistrum,

Iste suo semper fidus erat domino.

Ambo pontifices: Romanis ille, Polonis

Hic preest. Clarum scandit uterque polum.

Martirio ille, fide hic certant. Sed Sarmata cedit

Romano, sedeat quod pociore loco.

Bartholomeus Siekierzeczki

curie prefati olim r-mi d-ni archiepi

notarius manu propria subscripsit.

\section{KAROL GÓRSKI}

\section{ZAGINIONE ŹRÓDLO - RĘKOPIS AKT KAPITULNYCH ZGROMADZENIA XX. MARIANÓW Z LAT 1670-1767}

Konieczną jest rzeczą, by archiwa kościelne posiadały dokładne katalogi i by zbiory nie wędrowały po prywatnych osobach, gdyż w ten sposób.ulegają one zatracie. Publikujemy tu dane dotyczące takiego wlaśnie źródła, które w tej chwili należy uważać za zaginione.

Źródło to miałem $w$ ręku przez 48 godzin i sporządziłem jego opis wedle zasad obowiązujących. Opis taki dla źródła nowożytnego obejmować powinien: 1) określenie materiału (papier), wymiary w centymetrach, 2) opis oprawy, o ile możności z podaniem charakteru (deska, tektura, skóra, barwa jej, ozdoby); 3) opis zapisek i notatek na oprawie i poszczególnych kartach księgi; jeśli tych notat jest niewiele, należy podać je in extenso, z zaznaczeniem, jaką ręką są pisane. Może tu wchodzić w grę ręka pisarzy księgi czy dokumentu, albo ręka jednego z właścicieli, który się podpisał, albo rece nieznane; 4) wreszcie należy o ile możności dokładnie podać treść źródła tak, by czytelnik mógł siẹ zorientować jaką wartość posiadają dla niego opisywane materiały. Przy szczegółowym opisie należy posługiwać się Instrukcją wydawniczq dla źródeł historycznych od XVI do połowy XIX w. (Wrocław 1953). Przy tran- 